\title{
Explaining the Low Labor Productivity in East Germany - A Spatial Analysis
}

\author{
Nicola Fuchs-Schündeln and Rima Izem* \\ Harvard University
}

February 13, 2007

\begin{abstract}
This paper sheds light on the specificity or transferability of human capital by analyzing the unique event of German Reunification. We explore whether the comparatively low labor productivity in the East is caused by the depreciation of human capital at reunification, or by unfavorable job characteristics. East German workers should have been hit harder by reunification the more specific human capital was. Treating both human capital and job characteristics as unobservables, we derive their relative importance in explaining the low labor productivity by estimating a spatial structural model and analyzing the commuting behavior across the former East-West border and the resulting regional unemployment rates. The identification of the model comes from the slope of the unemployment rate across the former border: the larger the human capital differences between East and West, the less commuting across the border takes place, and the sharper is the increase of the unemployment rate at the former border. The results indicate that East and West German skills are very similar, while job characteristics differ significantly between East and West. They hence suggest that a significant part of the human capital accumulated in the East before 1990 was transferable.
\end{abstract}

\footnotetext{
${ }^{*}$ Nicola Fuchs-Schündeln, Department of Economics, Harvard University, nfuchs@harvard.edu. Rima Izem, Department of Statistics, Harvard University, izem@stat.harvard.edu. We thank Susanne Raessler and Katja Wolf from the IAB for wonderful hosting in Nuremberg, and for all their help and feedback with the data. We also thank Guido Imbens, Matthias Schündeln, and the seminar audiences at the Harvard Statistics Department, Spatial Econometrics Conference 2006 in Rome, and the Verein fuer Socialpolitik Annual Conference 2006 in Bayreuth for their feedback and suggestions. We thank Anders Hopperstedt from the Center of Geographic Analysis at Harvard for calculating the driving times between counties. Kirk Moore and Linjuan Qian provided excellent research assistantship. This research was partly funded by the William Milton Fund and a research grant by the Wheatherhead Center for International Affairs at Harvard University.
} 


\section{Introduction}

German reunification provides a unique case study on the transferability of human capital. ${ }^{1}$ According to traditional measures of human capital, like years of schooling or further education, the East German population was better educated at reunification than the West German population (e.g. Ragnitz, 2006). As far as human capital is very general and transferable, e.g. mostly consisting of general problem-solving, language or mathematical skills, the East German population should have fared very well in the new West German labor market. However, the content of education and on the job training might have differed substantially between both countries, and a lot of either job- or occupation-specific human capital should thus have depreciated at reunification.

Since German reunification in 1990, unemployment rates in East Germany have been stubbornly high. Figure 1 shows the mean unemployment rates by county (Kreis) between 1998 and 2004, as well as the former East-West border. ${ }^{2}$ There are 439 counties in Germany, of which 326 belong to the former West. The average population size of a county is 188,000 . On average, unemployment rates in the East are around twice as high as in the West.

By now, it is well established that the major cause of the high unemployment rates in the East lies in wages exceeding labor productivity (see e.g. Burda and Hunt, 2001). Figure 2 shows the East-West ratios of wages in addition to the East-West ratios of labor productivity from 1991 to 2004 . The trend in both ratios has been remarkably similar. There is rapid convergence between East and West until 1995, and from then on convergence has slowed down significantly, or even come to a halt. Most importantly, the East-West ratio of wages is always larger than the East-West ratio of labor productivity, and there is only a small and slow decline in the difference between both. Thus, it seems that wages in the East are too high relative to wages in the West, given the lower labor productivity. ${ }^{3}$

While the gap between wages and labor productivity has been established as the main reason for the high unemployment rates in the East, there is no consensus as to why labor productivity remains low in the East. Two different strands of explanations have been brought forward, and the goal of this paper is to differentiate between these two different explanations. The first set of

\footnotetext{
${ }^{1}$ The distinction between general skills and skills specific to a firm or occupation dates back at least to Becker (1964) and Mincer (1974), and has been analyzed in many theoretical and empirical contributions since.

${ }^{2}$ These data come from the Institut für Arbeitsmarkt- und Berufsforschung (IAB), and are the data that we use in our estimation.

${ }^{3}$ Ragnitz (2006) shows that a similar East-West gap exists when using alternative measures of productivity. Funke and Rahn (2002) provide a detailed analysis of the efficiency of firms in East Germany, and find that they are significantly less efficient than West German firms.
} 


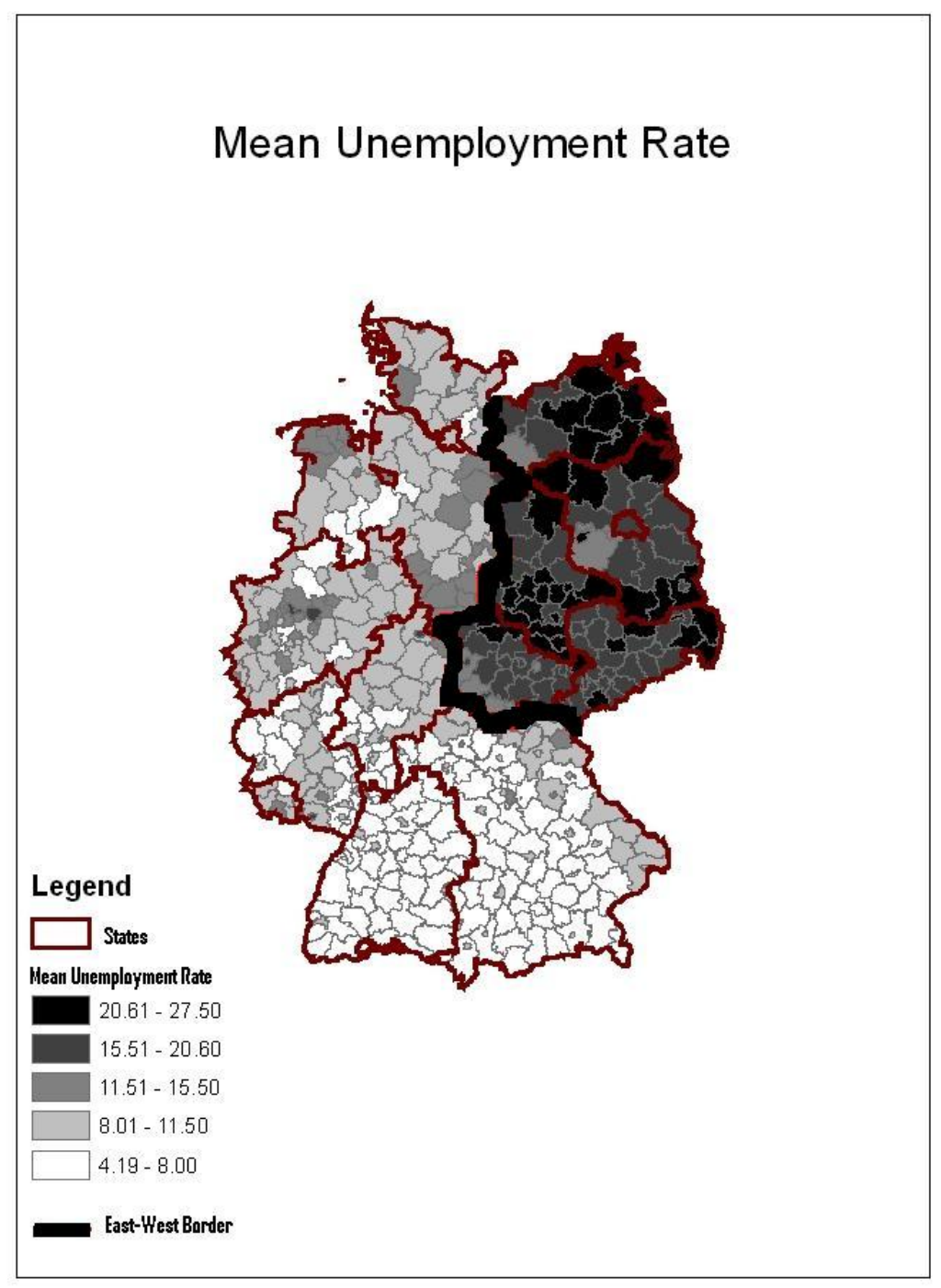

Figure 1: Mean Unemployment Rates in German Counties, from 1998 to 2004. 


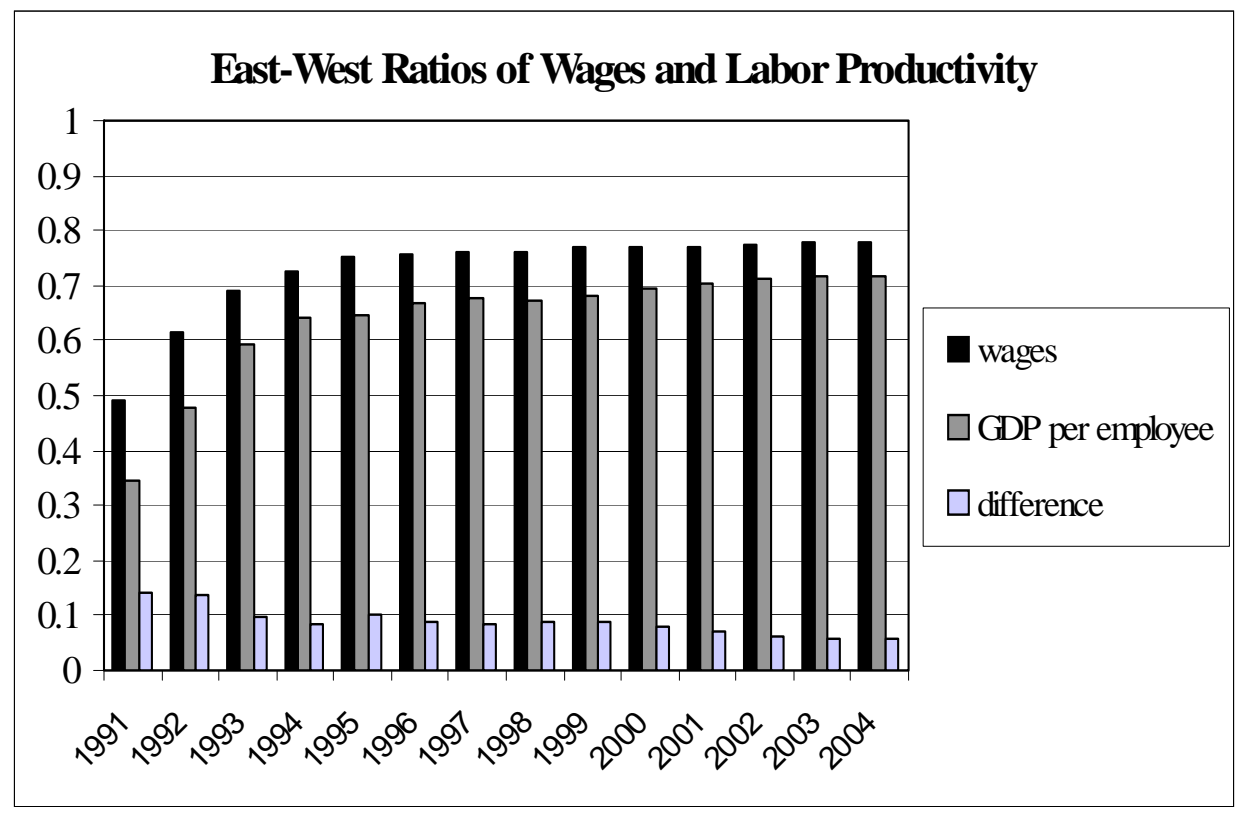

Figure 2: East-West wage and labor productivity gap, 1991-2004

hypotheses has to do with job characteristics, i.e. reasons outside the influence of an individual worker. Possible explanations range from firm sizes (Beer and Ragnitz, 1997), branch structure (Rothfels, 1997), the heterogeneity of factor endowments (Dietrich, 1997), agglomeration effects (Yellen, 2001), R\&D spending (Felder and Spielkamp, 1998), and network effects (Uhlig, 2006), to managerial and organizational deficiencies (Yellen, 2001; Mallok, 1996; Bellmann and Brussig, 1998; Ragnitz et al., 1998; Müller et al., 1998).

A completely different explanation sees the reason for the lower labor productivity in East Germany in worker characteristics. Formal educational levels in the GDR exceeded those of West Germans (see e.g. Klodt, 2000). Yet, it might be that there are unobserved differences in human capital between East and West German workers. Firm-specific or occupation-specific human capital might have depreciated at reunification since it did not match the skill requirements of firms using technologies typically used in West Germany (Ragnitz, 2006). Canova and Ravn (2000) assume that skill levels are on average lower in the East than in the West, claiming that much of the workers' human capital in the East was organization-specific.

We propose a novel method for differentiating between these two explanations, i.e. differences in worker characteristics or differences in job characteristics. Since skills and job characteristics are hard to quantify, they are to be estimated in our model. We estimate the East-West ratios of these unobservable characteristics by fitting a spatial economic model to the data. The model 
predicts the working and commuting behavior of individuals given the unobservables. ${ }^{4}$ More precisely, it models the effects of skills, job characteristics, and commuting on both the individual labor productivity, and the county-level unemployment rate. We are able to differentiate between worker and job characteristics as the causes for the low labor productivity because the predictions for commuting across the border differ under both hypotheses, resulting in different slopes of the unemployment rate across the former border. Essentially, if only worker characteristics cause the low labor productivity, then any unemployed worker in the East would not be able to find a job in the West either. On the other hand, if only job characteristics are less favorable in the East, then unemployed East Germans who live close to the border can commute to work in the West, thus depressing the unemployment rates in Eastern border counties, and increasing the unemployment rates in Western border counties. Figure 3 shows the county unemployment rates as a function of the distance to the former border. This distance is measured as a negative number for West German counties, and as a positive number for East German counties. The graph clearly shows that Western counties have lower unemployment rates than Eastern counties. Most importantly, counties at the former East-West border seem to have intermediate unemployment rates.

Our model relates to the literature that takes the location of jobs and workers in different markets into account. ${ }^{5}$ Tobin (1972) refers to "obsolescent industries and declining areas" when explaining why vacancies and unemployment coexist. Shimer (2006) analyzes the geographical and skill mismatch of unemployed workers and vacancies in a model in which wages adjust to clear regional labor markets, and firms decide how many vacancies to post, but movement of workers between the markets is exogenous. Taking the opposite approach, Lagos (2000) builds a model of the taxicab market in which the spatial location of demand and supply arises endogenously, but prices are exogenously fixed.

Like Lagos (2000), we assume that wages are exogenous. This seems reasonable in the context of Germany, due to the high rate of unionization and the political pressure to increase wages in the East quickly after reunification (see e.g. Snower and Merkl, 2006). While we assume that the number of jobs and the number of labor force participants in any county is fixed, regional labor supply is still an endogenous variable through the commuting decision of workers.

Our results indicate that the East-West ratio of job characteristics is smaller than the EastWest ratio of worker characteristics. In fact, skills do not differ significantly between East and

\footnotetext{
${ }^{4}$ Importantly, the model abstracts from migration. This assumption is discussed in detail in section 2.

${ }^{5}$ While our model refers purely to geographic labor markets, the literature often refers in addition to markets for different skill levels.
} 


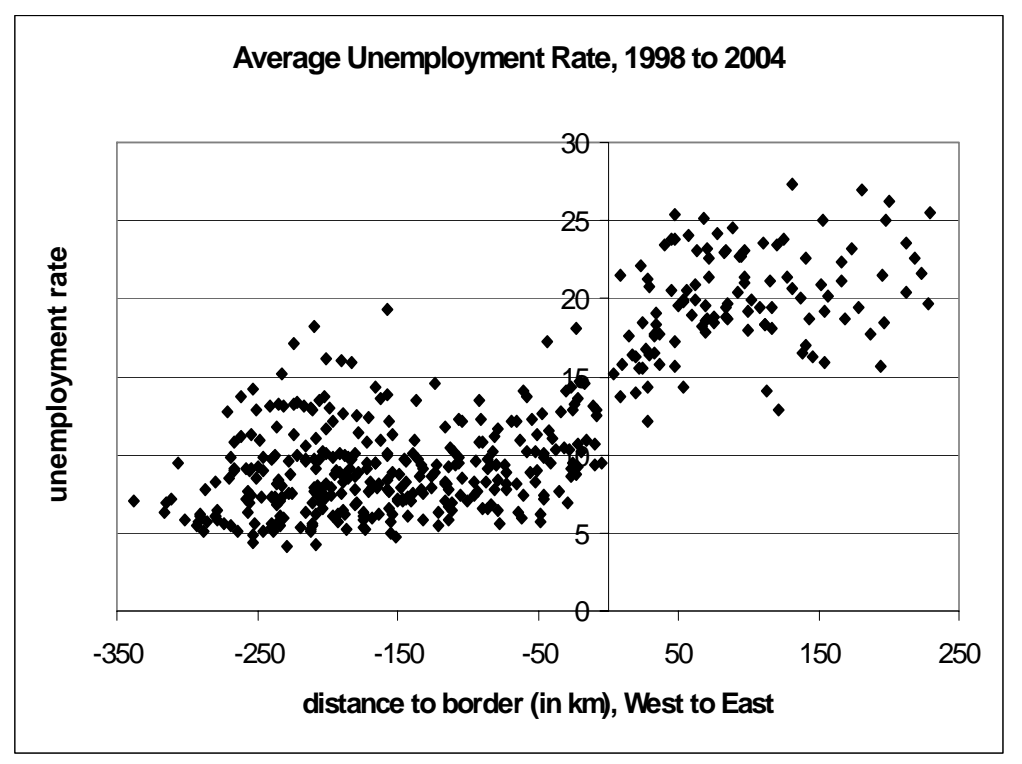

Figure 3: County unemployment rates as a function of distance to border. Negative distance indicates location west of the former border, positive distance indicates location east of the former border.

West, while job characteristics in the East are significantly less favorable than those in the West, in both economic and statistical terms. The results thus suggest that a large part of human capital was transferable at reunification. The model captures the spatial trend of the unemployment rate fairly well.

The model is presented in Section 2. That section also explains how we solve and calibrate the model. Section 3 introduces our estimation methodology, namely the method of simulated moments. Results of the estimation are shown in Section 4. Section 5 rules out some alternative explanations for the observed slope of the unemployment rate across the border. Finally, Section 6 concludes.

\section{The Model}

We assume that labor productivity depends on workers' skills $s_{i}$ and counties' job characteristics $I_{j}$, where subscript $i$ indicates an individual, and subscript $j$ a county. Skill and job characteristic distributions are the same for all counties in the East and all counties in the West, but they potentially differ between East and West. Specifically, we assume that individual skill levels $s_{i}$ are independent and normally distributed, but truncated at 0, with mean $S_{E}$ in East, $S_{W}$ in West, and the same variance $\sigma_{S}^{2}$. Counties' job characteristics $I_{j}$ are constant, and equal to $I_{E}$ in the 
former East and $I_{W}$ in the former West. Wages $w$ are homogeneous, exogenous, and the same in East and West.

Whether an individual $i$ is qualified to work in any county $j$ will depend on the marginal product of labor. The marginal product of labor of person $i$ in county $j$ is a function of worker and job characteristics. It is defined as

$$
\operatorname{mpl}_{i j}=\operatorname{mpl}\left(s_{i}, I_{j}\right)=s_{i} * I_{j}
$$

Firms in county $j$ will not be willing to employ individual $i$ if

$$
\operatorname{mpl}_{i j}<w
$$

The model abstracts from migration, implicitly assuming that migration costs are prohibitively high. Massive migration from the East to the West took place in the early 1990s. Yet, since then migration flows have been relatively small. It is well established that unobserved migration costs seem to be high in Germany, given that in general we do not observe significant migration flows in response to economic conditions (e.g. Schündeln, 2005, and Decressin, 1994). If we find significant differences in worker characteristics between East and West, these could be caused either by the different educational backgrounds, or by self-selected migration of high-skilled East German workers into the West.

Commuting is possible but costly in the model. The cost of commuting of person $i$ from home county $h$ to county $j$ is a function of the commuting distaste $\theta_{i}$ and the pairwise distance between counties $h$ and $j, d_{h j}$. We assume $\theta_{i} \sim U[1,2]$. The cost of commuting is defined as

$$
c_{i, h j}=c\left(\theta_{i}, d_{h j}\right)=\left(\alpha+\beta d_{h j}\right) \theta_{i}
$$

where $\alpha$ and $\beta$ are two parameters to be calibrated. An individual is willing to commute if the cost of commuting plus the wage is smaller than the unemployment benefit, which is equal to a fraction $\lambda$ of the wage

$$
c_{i, h j}<(1-\lambda) w
$$

With this setup, we propose a static model that puts a limit on the number of jobs available in each county, and incorporates competition on workers' skills. Each firm prefers a higher skilled over a lower skilled worker, and each worker prefers a job in a closer county to one further away. 
The number of jobs in each county is exogenously fixed, as is the number of individuals in the labor force in each county. We discussed the assumption of no migration above; given fixed costs of investment, the assumption of a fixed number of jobs seems reasonable for a relatively shortterm model like ours. Let $p_{i, h j}$ be the probability of an individual $i$ living in county $h$ to get a job in $j$, with a total number of jobs $n_{j}$ available in $j$, then

$$
\begin{aligned}
p_{i, h j} & =1-q_{i, h j} \\
q_{i, h j} & =P\left[C_{i, h j}^{c} \cup\left(C_{i, h j} \cap \sum_{k} \mathbb{I}\left(C_{k, h j} \cap D_{k i}\right) \geq n_{j}\right) \cup_{l}\left(C_{i, h l} \cap E_{i, h j l} \cap \sum_{k} \mathbb{I}\left(C_{k, h l} \cap D_{k i}\right)<n_{l}\right)\right] \text {, where } \\
C_{i, h j} & =\left\{\operatorname{mpl}_{i j} \geq w \text { and } c\left(\theta_{i}, d_{h j}\right) \leq 1\right\} \\
D_{k i} & =\left\{s_{k} \geq s_{i}\right\} \\
E_{i, h j l} & =\left\{c\left(\theta_{i}, d_{h j}\right)>c\left(\theta_{i}, d_{h l}\right)\right\}
\end{aligned}
$$

Summarizing, a person is qualified to work in a county if her marginal product of labor there is higher than the wage. She is willing to work in that county if the cost of commuting is not prohibitive. Among qualified individuals willing to commute, jobs are filled on a more skilled to less skilled order as long as there are vacancies in that county. All individuals seek to minimize the cost of commuting, and hence prefer a job in a county closer to home to one in a county further away. Thus, an individual $i$ from county $h$ will not be employed in county $j$ if either the individual is not qualified to work there or not willing to commute there $\left(C_{i, h j}^{c}\right)$, or the individual is qualified and willing, but all jobs are taken already by higher skilled individuals $\left(C_{i, h j} \cap \sum_{k} \mathbb{I}\left(C_{k, h j} \cap D_{k i}\right) \geq n_{j}\right)$, or the individual could work in $\mathrm{j}$, but finds employment in a county closer to home $\left(C_{i, h l} \cap E_{i, h j l} \cap \sum_{k} \mathbb{I}\left(C_{k, h l} \cap D_{k i}\right)<n_{l}\right)$.

Note that in this model a qualified individual is not guaranteed to work in her home county. It might be that either there are not enough jobs available for all qualified individuals living there, or that there are too many higher skilled workers in neighboring counties that would like to commute into the home county. This can generate commuting within the West and within the East. In addition, under the assumption that $I_{E}<I_{W}$, the model will result in commuting from the East to the West across the former border. This commuting occurs because some relatively high skilled individuals in the East cannot find a job there since their marginal product of labor is lower than the wage as a result of the unfavorable job characteristics. Yet, these individuals are skilled enough to find a job in the West, where the job characteristics are better. As a consequence, we 
also see more commuting in the westward direction within the East and within the West. The westward commuting within the West occurs because more skilled eastern workers fill western jobs, and less skilled western job seekers have to find a job further into the West. The westward commuting within the East occurs because the westward commuting of eastern workers close to the border opens vacancies there for eastern workers living further into the East.

\subsection{Solving the model}

Deriving the closed form of the distribution of the unemployment rate is not trivial in this case. However, the model can be solved numerically given the parameters of the unobservables. Given $I_{E}, I_{W}, S_{E}, S_{W}, \sigma_{S}^{2}$ and a matrix of pairwise driving times $D$ between the counties, let $N_{W}$ be the number of western counties, and $N_{E}$ the number of eastern counties, and let $l_{j}$ be the number of individuals in the labor force of county $j$. The algorithm is as follows:

1. Draw $\sum_{j=1}^{N_{W}} l_{j}$ independent $s_{i}$ 's in West and $\sum_{j=1}^{N_{E}} l_{j}$ independent $s_{i}$ 's in East from the appropriate distributions.

2. Draw $\sum_{j=1}^{N_{W}} l_{j}+\sum_{k=1}^{N_{E}} l_{k}$ independent $\theta_{i}$ 's from Uniform $[1,2]$.

3. Rank individuals from higher to lower skills.

4. For each individual, rank counties from smallest cost of commuting to highest cost.

5. Iterate the following steps, starting with individual with highest skills:

(a) Individual gets the job in closest county which has available job and where individual is willing and qualified to work.

(b) Update the number of jobs available.

6. Compute $U R_{j}$ 's by summing up the number of individuals in county $j$ that could not find a job, divided by the total number of individuals in county $j$.

\subsection{Calibration}

We set the wage equal to $w=1$, the unemployment replacement ratio equal to $\lambda=0.5$, and the variance of the skill distribution equal to $\sigma_{S}^{2}=1$. The total number of available jobs per county is equal to the number of people employed in each county in 2001, plus three times the number of 
vacancies posted at the employment agency for the respective county. ${ }^{6}$ The number of vacancies corresponds to vacancies posted at the employment office, and the IAB estimates that roughly a third of all vacancies are posted that way. The total number of people in the labor force per county is set equal to the labor force in each county, i.e. people living in each county who either work or are registered as unemployed. ${ }^{7}$

The distance between two counties is measured as the driving time between the closest points on a road to the centroids of the most populated Gemeinden of every county. ${ }^{8}$ All interstates (Autobahnen) and larger roads (Bundesstrassen) are taken into account in this calculation. We assume that the average driving speed on an interstate is $100 \mathrm{~km} / \mathrm{h}$, and on the other roads 60 $\mathrm{km} / \mathrm{h} .{ }^{9}$ With this measure of distance, we calibrate the cost of commuting to take the following form

$$
c\left(\theta_{i}, d_{h j}\right)=0.25 \theta_{i}\left[1+\frac{d_{h j}-d_{\min }}{d_{\max }-d_{\min }}\right]
$$

where $d_{\min }$ corresponds to the minimum one-way driving time everyone is willing to commute, and $d_{\max }$ to the maximum driving time beyond which nobody is willing to commute. ${ }^{10}$ We calibrate $d_{\min }=15$ minutes and $d_{\max }=100$ minutes based on the reported willingness to commute from two German surveys. One of those surveys (McKinsey et al., 2005) asks whether a respondent would be willing to commute up to 2 hours per day (i.e. two-way), and $31 \%$ of the respondents answer positively. In the other survey, conducted by the internet portal meinestadt.de in 2005, the mean one-way distance individuals are willing to commute corresponds to $41 \mathrm{~km}$. $75 \%$ of respondents are willing to commute up to $20 \mathrm{~km}, 50 \%$ up to $30 \mathrm{~km}, 25 \%$ up to $50 \mathrm{~km}$, and $10 \%$ up to $70 \mathrm{~km} .{ }^{11}$ Figure 4 shows the percentage of the population willing to commute a certain amount of time under our calibration, and it matches the numbers from the surveys very well.

\section{Identification and estimation}

We estimate the model using the method of simulated moments. For normalization purposes, we fix $I_{W}=1$. The parameters to be estimated are the mean skills ratio $\frac{S_{E}}{S_{W}}$, the job characteristics

\footnotetext{
${ }^{6}$ The data of people employed in each county, which includes employees, self-employed, and civil servants, as well as the data of vacancies was made available to us by the IAB.

${ }^{7}$ Again, the number of people working includes employees, self-employed, and civil servants.

${ }^{8}$ There are between 6 and 235 Gemeinden in a county (Kreis).

${ }^{9}$ Note that the average speed is smaller than the legal speed limit.

${ }^{10}$ Thus, an individual is willing to commute if $0.25 \theta_{i}\left[1+\frac{d_{h j}-d_{\min }}{d_{\max }-d_{\min }}\right]<0.5 \Leftrightarrow 0.5 \theta_{i}\left[1+\frac{d_{h j}-d_{\min }}{d_{\max }-d_{\min }}\right]<1$.

${ }^{11}$ This survey question was answered by 10,006 respondents. The survey from Perspektive Deutschland was answered by 510,000 individuals.
} 


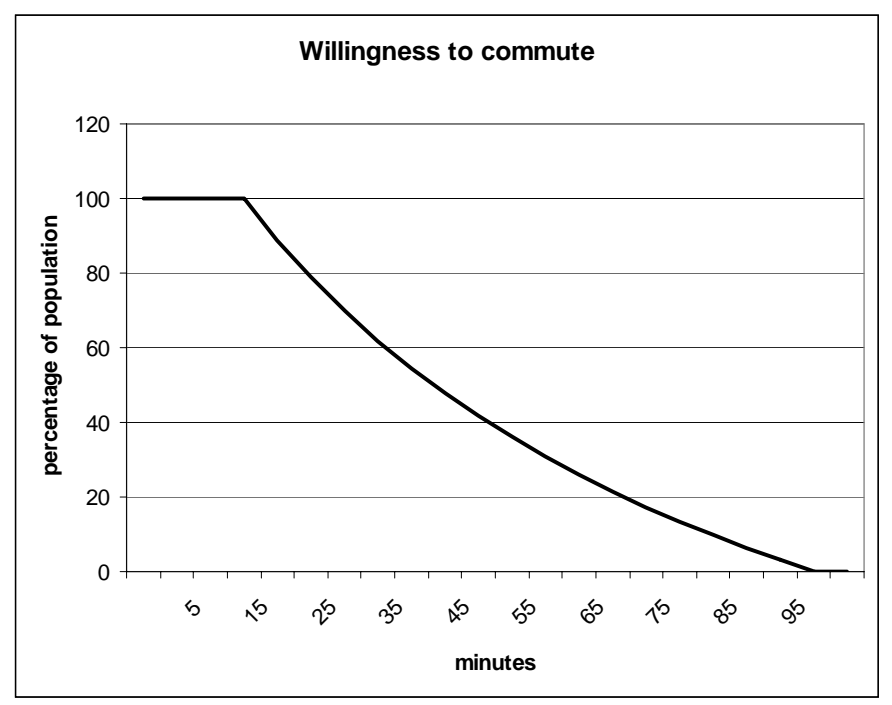

Figure 4: Percentage of population willing to commute a certain number of minutes (one-way)

ratio $\frac{I_{E}}{I_{W}}$, and also the mean skills in the West $S_{W}$. Thus, our parameter vector $\beta$ comprises $\beta=\left\{S_{W}, \frac{I_{E}}{I_{W}}, \frac{S_{E}}{S_{W}}\right\}$.

The identification of the model comes from the regional behavior of the unemployment rate, and especially the behavior of the unemployment rate around the border. Given $I_{W}, S_{W}$ pins down the average unemployment rate in the West. Any decrease in the East-West worker or job characteristic ratios leads to an increase in the difference of the mean unemployment rates between East and West. However, a decrease in the East-West skill ratio leads to a sharper increase in unemployment rates at the border, while a decrease in the East-West ratio of job characteristics leads to a flatter increase; i.e. the effect on the slope of the unemployment rate across the border goes in different directions.

Given this identification, we choose to approximate the slope of the unemployment rate along the border through a step function, and to match the average unemployment rates of 10 regions. For East and West separately, we construct the average unemployment rate of all counties within 15 minutes driving time to the border, those with a driving time to the border between 15 and 30 minutes, between 30 and 45 minutes, between 45 and 60 minutes, and all counties with a driving time to the border of more than an hour. ${ }^{12}$ Figure 5 shows the average unemployment rates of these regions; they are monotonically increasing as one moves from West to East.

\footnotetext{
${ }^{12}$ Since there is not much variation in the average unemployment rates further than 60 minutes away from the border, and since most of our identification comes from the border area, we choose not to break down the region beyond 60 minutes from the border into further subregions.
} 


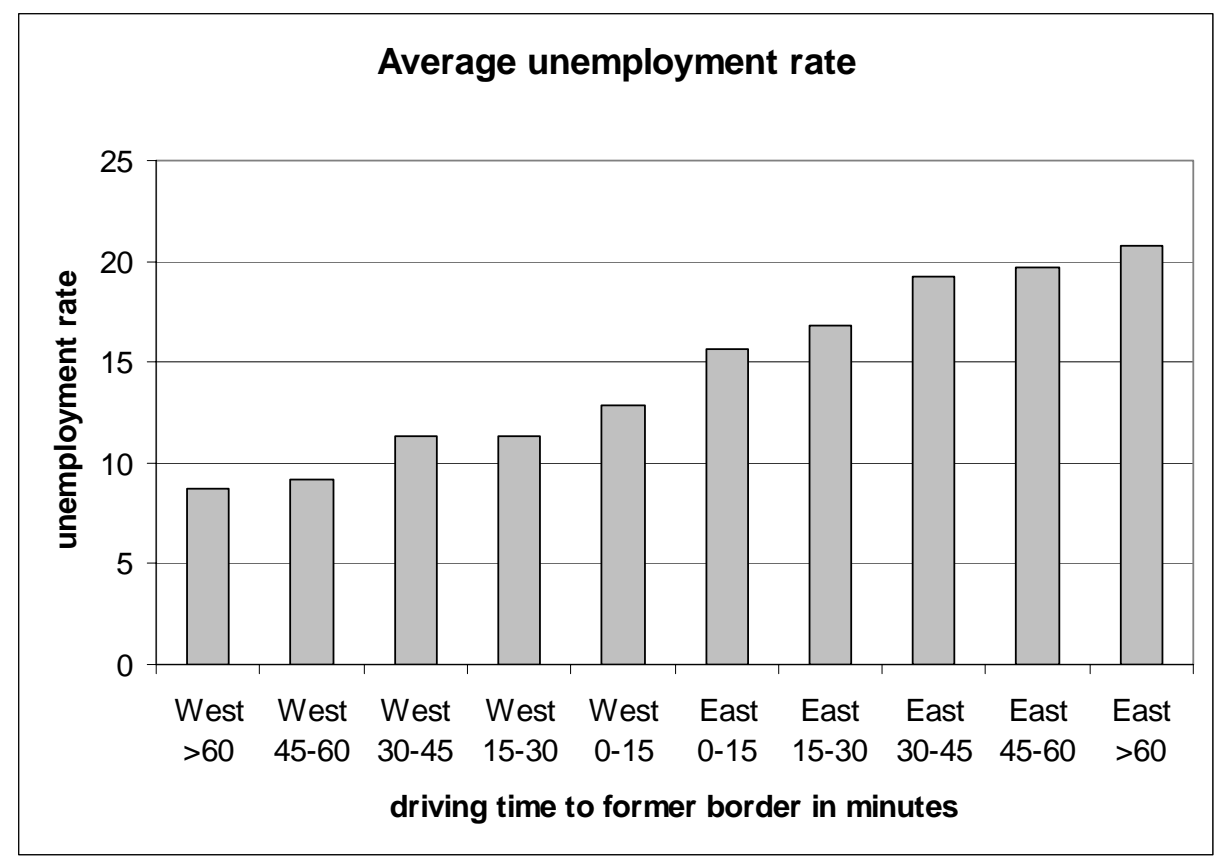

Figure 5: Average unemployment rates of different regions, constructed according to driving time to former border

Let $U R^{t}\left(S_{W}, \frac{I_{E}}{I_{W}}, \frac{S_{E}}{S_{W}}\right)$ be the average unemployment rate of region $t$, and let $U R_{j}^{t}$ be the unemployment rate of county $j$ in region $t$. Moreover, $S_{W_{0}}, \frac{I_{E}}{I_{W}}, \frac{S_{E}}{S_{W}}$ are the true parameter values. For every region $t$, the following moment condition holds

$$
E\left(U R_{j}^{t}-U R^{t}\left(S_{W_{0}}, \frac{I_{E}}{I_{W}}, \frac{S_{E}}{S_{W}}\right)\right)=0
$$

We use the method of simulated moments to find the parameter estimates that minimize

$$
\min _{S_{W}, \frac{I_{E}}{I_{W}}, \frac{S_{E}}{S_{W}}} \widehat{M}\left(S_{W}, \frac{I_{E}}{I_{W}}, \frac{S_{E}}{S_{W}}\right)^{\prime} W \widehat{M}\left(S_{W}, \frac{I_{E}}{I_{W}}, \frac{S_{E}}{S_{W}}\right)
$$

where $\widehat{M}\left(S_{W}, \frac{I_{E}}{I_{W}}, \frac{S_{E}}{S_{W}}\right)$ is a column vector of size $t$, and each element of $\widehat{M}$ equals the empirical counterpart $\widehat{M}^{t}=\frac{1}{N^{t}} \sum_{j \in t}\left(U R_{j}^{t}-\widehat{U R}_{S}^{t}\left(S_{W}, \frac{I_{E}}{I_{W}}, \frac{S_{E}}{S_{W}}\right)\right)$ of the above stated moment condition. $N^{t}$ is the number of counties in region $t$, and $\widehat{U R}_{S}^{t}\left(S_{W}, \frac{I_{E}}{I_{W}}, \frac{S_{E}}{S_{W}}\right)$ is the vector of average simulated regional unemployment rates, given the parameters $S_{W}, \frac{I_{E}}{I_{W}}, \frac{S_{E}}{S_{W}}$.

We apply a two-step procedure. In the first step, the weight matrix is equal to the identity matrix, $W=I$. This step provides first consistent estimates of our parameter vector. Moreover, 
it allows us to construct an estimate of the variance-covariance matrix $\widehat{\Omega}$. In the second step, we use the inverse of this matrix as the weight matrix, $W=\widehat{\Omega}^{-1}$, reoptimize, and get efficient

estimates of our parameter vector. Using the matrix $\widehat{\Omega}$ and the numerical derivatives $\frac{\partial \widehat{U R}_{S}^{t}}{\partial \beta}$, we can also construct standard errors for the estimates.

We solve the model using pattern search as a minimization algorithm. While the criterion function of this problem is convex, it is not continuous due to the discretization into counties, necessitating a minimization algorithm that does not use the gradient to search for an optimal point. We divide both the number of jobs and the number of people in the labor force by 100, and use 300 simulations.

\section{Results}

\begin{tabular}{|c|lc|}
\hline & coeff. & std. error \\
\hline$S_{W}$ & 2.4430 & 0.1038 \\
$\frac{I_{E}}{I_{W}}$ & 0.6235 & 0.1538 \\
$\frac{S_{E}}{S_{W}}$ & 1.0750 & 0.0711 \\
\hline
\end{tabular}

Table 1:

Results

Table 1 presents the results. The East-West skill ratio amounts to 1.075. Thus, it is even slightly larger than 1 , though clearly not statistically significantly so.

In contrast, the East-West ratio of job characteristics lies at 0.62 , and is significantly different from 1 not only in a statistical, but also in an economic sense. Hence, our results indicate that unfavorable job characteristics in the East seem to be the main driving force of the low labor productivity there. The magnitude of the job characteristic differences between East and West is surprisingly high. Yet, we want to stress again that "job characteristics" in our model capture anything that has a positive influence on labor productivity, but cannot be directly influenced by the worker (e.g. infrastructure, managerial quality, physical capital, network effects between firms). Clearly, several of these factors could be at play, and could together explain the large difference. Maybe somewhat surprisingly, worker characteristics in East and West are indistinguishable in our sample period. Thus, either human capital accumulated in the East did not depreciate at reunification, or public policies with regard to retraining seem to have been very successful. On the other hand, the large financial subsidy programs encouraging firms to settle in the East somehow seem to have failed to produce the same quality of jobs there than in the West. 


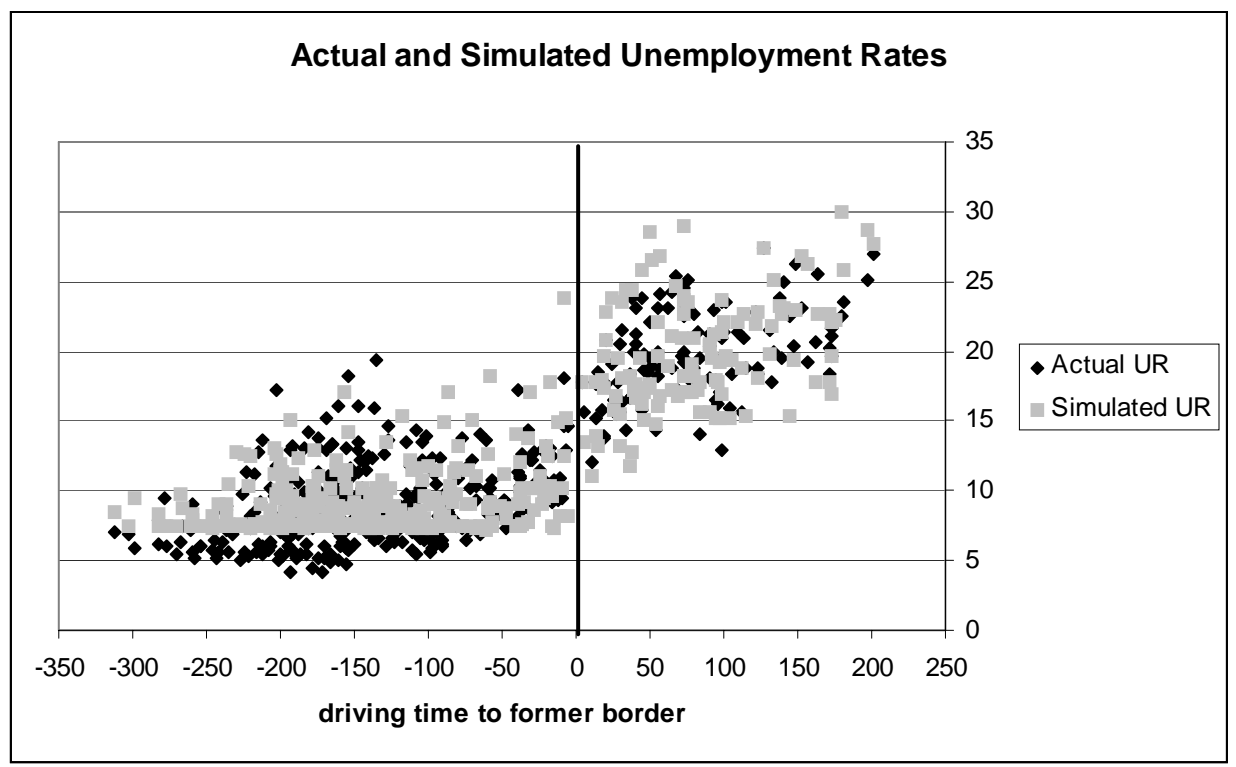

Figure 6: Actual and simulated unemployment rates as a function of driving time to former East-West border

Early retirement policies after reunification probably make the picture more favorable for skill differences than it would otherwise have been. On the other hand, selected migration might have lowered the mean skills in the East (Hunt, 2006). We provide further discussion of the results in the conclusion.

Figure 6 shows the resulting simulated unemployment rates for the counties based on 300 simulations, plotted against the driving time to the border, as well as the actual unemployment rates from the data. Our model matches the slope fairly well, but fails to produce enough variation in the Western counties more than 100 minutes away from the border. This is not surprising, given that in the model the only heterogeneity of counties within the East or within the West arises through the calibrated number of jobs and number of people in the labor force.

\section{Alternative Hypotheses}

The model explains the slope of the unemployment rate along the border through commuting behavior. However, one could potentially imagine other reasons for the gradual increase in the unemployment rates along the former border. 


\subsection{Market Access}

Redding and Sturm (2005) stress the importance of market access in explaining differences in economic performance. They find that, after separation, West German cities close to the EastWest border grew significantly slower than other Western German cities, and argue that this is due to the cut-off of market access after 1945. The market access hypothesis could explain why unemployment rates are increasing from West to East in Germany, since trade barriers are smaller within Germany or between Germany and the EU neighbors on the West than between Germany and the Eastern European countries which only became members of the EU in $2004 .{ }^{13}$

One can test for this hypothesis by analyzing unemployment rates before reunification, when the border between East and West was insurmountable. The market access hypothesis implies that the increase in the unemployment rate in West Germany as one moves towards the border should already have existed and should have been even more pronounced before reunification. While implications of this hypothesis cannot be tested for East Germany, in which unemployment was largely hidden, we can analyze the spatial behavior of the unemployment rate in West Germany before reunification. To this end, we use the average unemployment rates of the years 1987 and 1988 on the county level. Figure 7 shows the average unemployment rates plotted against the distance to the border, in 1987 to 1988 and 1998 to 2004, respectively. ${ }^{14}$ Eyeballing these scatter plots, an increase in the unemployment rate close to the border is apparent in the figure for 1998 to 2004 , but not in 1987 to 1988 .

To test whether the unemployment rate is indeed significantly increasing towards the border in 1998 to 2004, but not in 1987 to 1988, we run two regressions separately for both time periods. In the first, we regress the unemployment rate on a constant and a border dummy, which takes on the value of 1 if the county lies within $75 \mathrm{~km}$ of the East-West border. ${ }^{15}$ In the second, we regress the unemployment rate on a constant and on the distance to the former border. ${ }^{16}$ The results are shown in table 2 . While the border dummy and the distance to border variable both have highly significant coefficients with the expected sign in 1998 to 2004, indicating an increase in the unemployment rate as one moves towards the border, both variables are insignificant in

\footnotetext{
${ }^{13}$ However, one might still think that trade barriers are lowest within Germany, and slightly higher between Germany and its EU-neighbors. That should lead to slighlty higher unemployment rates along the Western border as well.

${ }^{14} \mathrm{As}$ in figure 3 above, the distance is expressed negatively, such that the "border" is located at the right ("Eastern") axis.

${ }^{15}$ This threshold is the same one as used by Redding and Sturm (2005). There are 60 counties within $75 \mathrm{~km}$ of the border.

${ }^{16}$ Note that, in contrast to the figures, distance is a positive number in the regressions.
} 

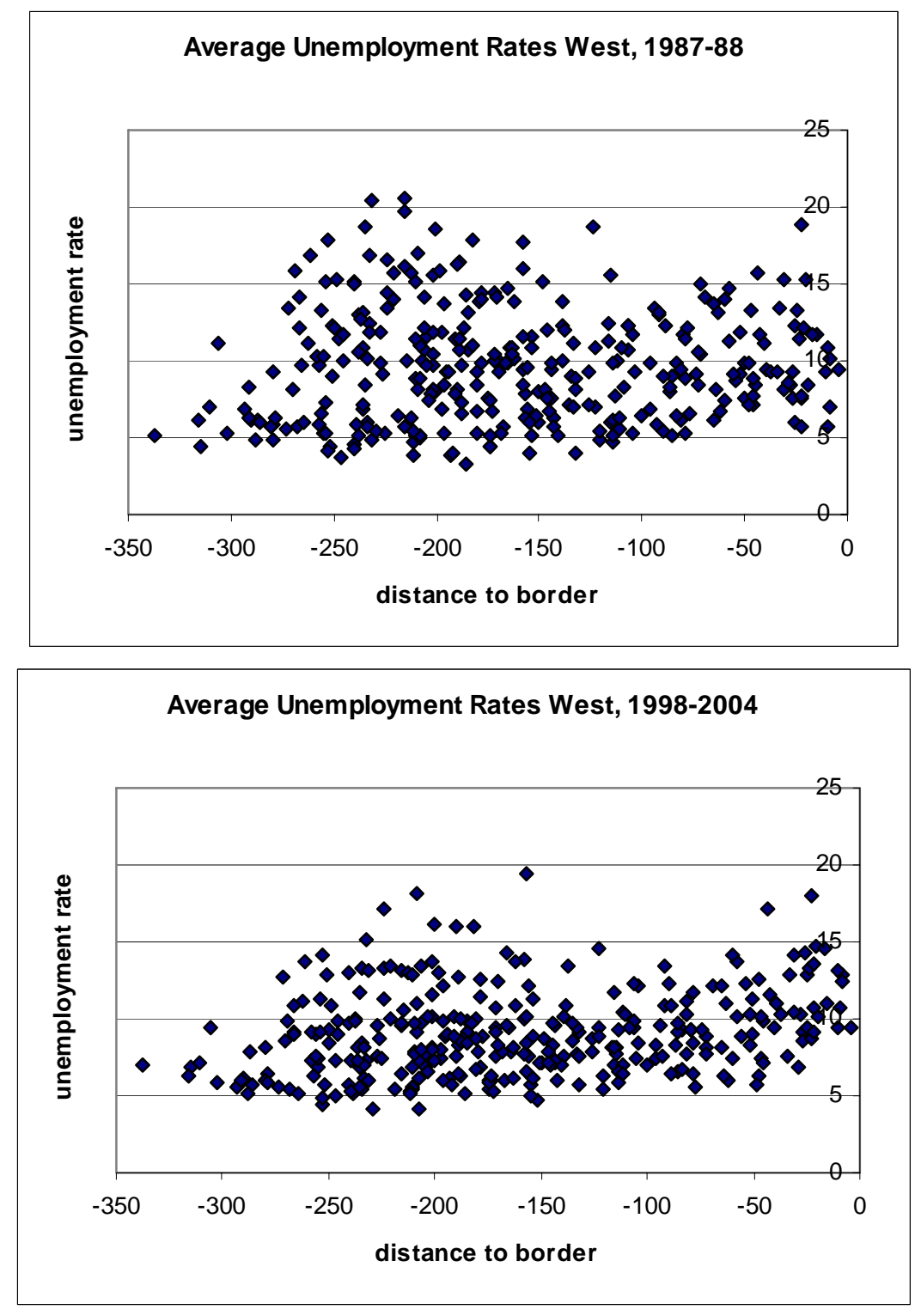

Figure 7: Average unemployment rates of West German counties as a function of distance to East-West border, 1987 to 1988 and 1998 to 2004 
the regressions for 1987 to 1988. Thus, the border area suffers from higher unemployment rates than the rest of West Germany in the time period 1998 to 2004, but not in the years immediately prior to reunification. This makes it unlikely that market access can explain this phenomenon. ${ }^{17}$

\begin{tabular}{|c|c|c|c|c|c|c|c|c|}
\hline \multirow{2}{*}{$\begin{array}{l}\text { Dependent variable: } \\
\text { unemployment rate }\end{array}$} & \multicolumn{4}{|c|}{$1987-1988$} & \multicolumn{4}{|c|}{$1998-2004$} \\
\hline & coeff. & std.err. & coeff. & std.err. & coeff. & std.err. & coeff. & std.err. \\
\hline border dummy & 0.687 & 0.521 & & & $1.837^{* * *}$ & 0.389 & & \\
\hline $\begin{array}{l}\text { distance to border } \\
\text { constant }\end{array}$ & $9.545^{* * *}$ & 0.223 & $\begin{array}{l}-0.002 \\
9.988^{* * *}\end{array}$ & $\begin{array}{l}0.003 \\
0.458\end{array}$ & $8.707^{* * *}$ & 0.166 & $\begin{array}{l}-0.009^{* * *} \\
10.515^{* * *}\end{array}$ & $\begin{array}{l}0.002 \\
0.340\end{array}$ \\
\hline R-squared & 0.005 & & 0.002 & & 0.06 & & 0.07 & \\
\hline
\end{tabular}

*** indicates significant at the $1 \%$ significance level

Table 2:

Regressions of West county unemployment rates on distance to border (measured as a positive number), 1987-1988 and 1998-2004.

\subsection{Migration and Investment}

Two other alternative hypotheses have to do with the spatial allocation of factors of production. Note especially that our model so far assumes that everyone living in East Germany between 1998 and 2004 is an "East German" in the sense that he or she lived in the German Democratic Republic before 1990, and the other way round for West Germany. It could be possible that either human capital or physical capital are allocated in Germany such that the level and quality is gradually decreasing as one moves from West to East. In that case, the unemployment rate would gradually increase even if all factors of production were only employed in the home county, and thus there would be no commuting.

With regard to human capital, this would mean that skill levels are not only higher in West Germany than in the East, but gradually increasing as one crosses the border. Under the assumption that Eastern skills depreciated somewhat at reunification, for the Eastern side of the border this would mean that either more "West Germans", i.e. individuals who acquired human capital in the West, are settled there than in the rest of the East, or on average higher skilled people are settled there than in the rest of the East. For the Western side of the border, this would mean that either more "East Germans", i.e. individuals who acquired human capital in the GDR, or lower skilled people, settled there than in the rest of the West.

\footnotetext{
${ }^{17}$ The former border areas (Zonenrandgebiete) received special federal subsidies before reunification. It could be that these subsidies were so effective that they completely took care of the negative effect of the lack of market access. Yet, Redding and Sturm (2005) find that they were not effective enough to overcome the negative effect on population growth in the border area.
} 
To get some insights into the issue of migration and the allocation of skills, we analyze data from the 2001 round of the German Socio-Economic Panel. ${ }^{18}$ From the German Socio-Economic Panel, we get information for every county about the estimated percentage of the population that is originally from East Germany. We identify a person as someone who lived in East Germany before 1990 if the person either belongs to the "East Germany" sample that was added to GSOEP in the spring of 1990, or if the person reports having a GDR-education. Moreover, we derive the highest educational degree of the respondent, analyzing the categories college, vocational training, secondary schooling, and no school degree, and then calculate the percentage of respondents within a county belonging to each educational category. We regress both the East/West composition and the educational attainment on border dummies, as well as on distance to border. Analogous to our calibration above, distance to border is now defined as driving time. ${ }^{19}$ We separately create a West border dummy for counties within 60 minutes driving time to the West of the former border, and an East border dummy for counties within 60 minutes driving time to the East. Tables 3 and 4 show the results.

As table 3 shows, a relatively higher percentage of the population in the Western border counties is from the former East Germany, and the percentage of the population from the former West is generally increasing as one moves away from the border in the West. However, in East Germany the composition of the population does not seem to be influenced by the distance to the border. Moreover, table 4 shows that the skill composition is not significantly different in the border areas from the rest in either East or West. We test this by analyzing the percentage of the population with college degree, but similar results arise if we group people with college or vocational degree together, or if we separately analyze college degrees received in the former East Germany and those received in West Germany. Summarizing, there is only weak evidence that the skill composition differs between counties, and any evidence comes from West Germany alone. However, even in West Germany the quantities are relatively small: while $95.6 \%$ of the population living in West German counties is from the former West, this percentage declines to $91.5 \%$ in the Western border counties.

Last, we assume that job characteristics are homogeneous within East and West. It could however be that investment behavior was heterogeneous, and hence the quantity and quality of physical capital is increasing gradually along the border. Yet, there should be a reason for this,

\footnotetext{
${ }^{18}$ The 2001 round is used since this is the midpoint of the time period under consideration in our paper.

${ }^{19}$ Results are qualitatively similar if we measure distance in kilometers, and define the border dummies as above.
} 
and hence this hypothesis is confounded with the hypothesis of market access above. ${ }^{20}$

\begin{tabular}{|c|c|c|c|c|c|c|c|c|}
\hline \multirow{2}{*}{$\begin{array}{l}\text { Dependent variable: } \\
\% \text { of West Germans }\end{array}$} & \multicolumn{4}{|c|}{ West Germany } & \multicolumn{4}{|c|}{ East Germany } \\
\hline & coeff. & std.err. & coeff. & std.err. & coeff. & std.err. & coeff. & std.err. \\
\hline West border dummy & $-0.041^{* * *}$ & 0.012 & & & & & & \\
\hline $\begin{array}{l}\text { East border dummy } \\
\text { time to border }\left(* 10^{3}\right)\end{array}$ & & & $0.207^{* * *}$ & 0.061 & -0.042 & 0.029 & -0.011 & 0.011 \\
\hline constant & $0.956^{* * *}$ & 0.004 & $0.921^{* * *}$ & 0.010 & $0.117^{* * *}$ & 0.018 & $0.080^{* * *}$ & 0.013 \\
\hline R-squared & 0.035 & & 0.034 & & 0.018 & & 0.001 & \\
\hline
\end{tabular}

*** indicates significant at the $1 \%$ significance level

Table 3:

Regressions of percentage of West Germans in population on distance to border (measured as a positive number in both East and West), 2001.

\begin{tabular}{|c|c|c|c|c|c|c|c|c|}
\hline \multirow{2}{*}{$\begin{array}{l}\text { Dependent variable: } \\
\% \text { college degree }\end{array}$} & \multicolumn{4}{|c|}{ West Germany } & \multicolumn{4}{|c|}{ East Germany } \\
\hline & coeff. & std.err. & coeff. & std.err. & coeff. & std.err. & coeff. & std.err. \\
\hline West border dummy & -0.007 & 0.019 & & & & & & \\
\hline $\begin{array}{l}\text { East border dummy } \\
\text { time to border }\left(* 10^{3}\right)\end{array}$ & & & 0.044 & 0.096 & -0.020 & 0.024 & 0.116 & 0.238 \\
\hline constant & $0.167^{* * *}$ & 0.007 & $0.154^{* * *}$ & 0.015 & $0.234^{* * *}$ & 0.014 & $0.215^{* * *}$ & 0.023 \\
\hline R-squared & 0.001 & & 0.001 & & 0.007 & & 0.002 & \\
\hline
\end{tabular}

Table 4:

Regressions of percentage of population with college degree on distance to border (measured as a positive number in both East and West), 2001.

\section{Conclusion}

This paper presents a novel method for estimating the gap in East-West worker and job characteristics. We build a model of commuting and differentiate between both hypotheses by analyzing the behavior of the unemployment rate across the former East-West border. The estimation results suggest that the lower labor productivity in the East can be explained by significantly less favorable job characteristics, but that worker characteristics do not differ significantly between East and West. While it might be reasonable to assume that human capital depreciated somewhat at reunification, it seems that 8 to 14 years were enough to overcome the differences in human capital. Some people, e.g. Canova and Ravn (2000), conjectured that it would take much longer than this. Our estimate is however in line with the view of the Deutsche Bundesbank (1996),

\footnotetext{
${ }^{20}$ Investment subsidies were generally quite homogeneous across East Germany.
} 
which suggested that the retraining period for the East German workforce would be approximately 12-14 years.

The estimates also suggests that a significant part of the human capital accumulated in the GDR was transferable, and not organization-specific or firm-specific. Thus, our model also sheds some light on the more general question of the specificity or transferability of human capital. To the extent that general education teaches problem solving skills that can then be applied in vastly different environments, one might not have expected a difference in East and West skills, given the on average even slightly higher number of years of education in the former GDR. To the extent that human capital is mostly specific to an occupation or even a firm, the depreciation of East Germans' human capital at reunification should have been significant. In future work, we plan to analyze the skill and job characteristic differences in the early 1990s, i.e. shortly after reunification. ${ }^{21}$ This should allow us to differentiate more clearly whether the depreciation of human capital at reunification was small, or whether the subsequent accumulation of human capital was very rapid.

The results hence suggest that reasons outside the individual worker's responsibilities in the East are to blame for the low labor productivity. These include factors in the influence of a single firm (e.g. managerial quality, investment in physical capital), as well as factors that are in the realm of public policy (e.g. public infrastructure), or that need some form of implicit or explicit cooperation between firms (e.g. network effects). Clearly, several of these factors could be at play, and could together explain the large East-West difference of job characteristics. Differentiating between these reasons is necessary for further policy conclusions, and constitutes a very important research agenda.

\section{References}

[1] Becker, Gary S. (1964): Human Capital, University of Chicago Press.

[2] Beer, S. and Ragnitz, J. (1997): Betriebsgröße und Arbeitsproduktivität im ostdeutschen Verarbeitenden Gewerbe, IWH, Wirtschaft im Wandel, 16, 11-13.

\footnotetext{
${ }^{21}$ County level unemployment rates are not available for the Eastern counties for this time period, and thus we will have to recur to a different spatial unit, namely the districts of the unemployment agency
} 
[3] Bellmann, L. and Brussig, M. (1998): Ausmaß und Ursachen der Produktivitätslücke ostdeutscher Betriebe im Verarbeitenden Gewerbe, Mitteilungen aus der Arbeitsmarkt- und Berufsforschung, 1998(4), 648-660.

[4] Blanchard, Olivier Jean, and Lawrence F. Katz (1992): Regional Evolutions, Brookings Papers on Economic Activity, 1992/1, 1-75.

[5] Burda, Michael C. and Hunt, Jennifer (2001): From Reunification to Economic Integration: Productivity and the Labor Market in Eastern Germany, Brookings Papers on Economic Activity, 2001(2), 1-71.

[6] Canova, Fabio and Ravn, Morten O. (2000): The Macroeconomic Effects of German Unification: Real Adjustments and the Welfare State, Review of Economic Dynamics, 3, 423-460.

[7] Conley, Timothy G. and Giorgio Topa (2002): Socio-Economic Distance and Spatial Patterns in Unemployment, Journal of Applied Econometrics, 17, 303-327.

[8] Decressin, Jörg (1994): Internal Migration in West Germany and Implications for East-West Salary Convergence, Weltwirtschaftliches Archiv, 130(2), 231-257.

[9] Deutsche Bundesbank (1996): The Debate on Public Transfers in the Wake of German Reunification, Monthly Report of Deutsche Bundesbank, 48(10), 17-30.

[10] Dietrich, V. (1997): Kapitalausstattung und Produktivitätsrückstand, IWH, Wirtschaft im Wandel, 7, 5-9.

[11] Felder, J. and Spielkamp, A. (1998): Innovationsstrategien und Forschungsaktivitäten ostdeutscher Unternehmen, in: Fritsch, M. Meyer-Krahmer, F. and Pleschak, F. (eds.): Innovationen in Ostdeutschland - Potentiale und Probleme, Physica, Heidelberg.

[12] Funke, Michael and Jörg Rahn (2002): How Efficient is the East German Economy?, Economics of Transition, 10(1), 201-223.

[13] Hunt, Jennifer (2006): Staunching Emigration from Eastern Germany: Age and the Determinants of Migration, Journal of the European Economic Association, 4(5), 1014-1037.

[14] Kline, Patrick (2006): Understanding Sectoral Labor Market Dynamics: An Equilibrium Analysis of the Oil and Gas Field Services Industry, mimeo. 
[15] Klodt, Henning (2000): Industrial Policy and the East German Productivity Puzzle, German Economic Review, 1(3), 315-333.

[16] Lagos, Ricardo (2000): An Alternative Approach to Search Frictions, Journal of Political Economy, 108(5), 851-873.

[17] Mallok, J. (1996): Engpässe in ostdeutschen Fabriken: Technikausstattung, Technikeinsatz, und Produktivität im Ost-West-Vergleich, Berlin.

[18] McKinsey, stern, ZDF, AOL (2005): Projektbericht Perspektive-Deutschland 2004/05.

[19] Mincer, Jacob (1974): Schooling, Experience, and Earnings, Columbia University Press.

[20] Müller, G. J. Rothfels, and A. Wölfl (1998): Determinanten der Produktivitätslücke in Ostdeutschland - Ergebnisse eines Workhops am IWH, Teil II, IWH, Wirtschaft im Wandel, 2, $15-21$.

[21] Ragnitz, Joachim (2006): Humankapital und Produktivität in Ostdeutschland, mimeo, IWH.

[22] Ragnitz, J., J. Rothfels, and A. Wölfl (1998): Determinanten der Produktivitätslücke in Ostdeutschland - Ergebnisse eines Workhops am IWH, Teil I, IWH, Wirtschaft im Wandel, $1,3-11$.

[23] Redding, Stephen, and Daniel M. Sturm (2005): The Costs of Remoteness: Evidence from German Division and Reunification, mimeo.

[24] Rothfels, J. (1997): Die ostdeutsche Wirtschaftsstruktur und die Produktivitätslücke, IWH, Wirtschaft im Wandel, 13, 15-21.

[25] Schündeln, Matthias (2005): Are Immigrants More Mobile Than Natives? Evidence From Germany, Harvard University.

[26] Shimer, Robert (2006): Mismatch, mimeo, August 2006.

[27] Snower, Dennis J. and Christian Merk (2006): The Caring Hand that Cripples: The East German Labor Market after Reunification, American Economic Review Papers \& Proceedings, 96(2), 375-382.

[28] Tobin, James (1972): Inflation and Unemployment, American Economic Review, 62 (1/2), $1-18$. 
[29] Topa, Giorgio (2001): Social Interactions, Local Spillovers and Unemployment, Review of Economic Studies, 68(2), 261-295.

[30] Topel, Robert H. (1986): Local Labor Markets, Journal of Political Economy, 94(3), S111S143.

[31] Uhlig, Harald (2006): Regional Labor Markets, Network Externalities and Migration: The Case of German Reunification, American Economic Review Papers \& Proceedings, 96(2), 383-387.

[32] Yellen, Janet (2001): Discussion of "From Reunification to Economic Integration: Productivity and the Labor Market in Eastern Germany", Brookings Papers on Economic Activity, 2001 (2). 